\title{
BUDŽETIRANJEM DO SIGURNIJEG POSLOVANJA I RAZVOJA PODUZEĆA
}

\author{
mr. sc. Željko Tintor \\ RETRA d.o.o. za reviziju i poslovno savjetovanje \\ Lastovska 6., 10000 Zagreb, Republika Hrvatska \\ GSM 091615 9292, e-mail: retra@zg.htnet.hr
}

\section{SAŽETAK}

Najznačajnija zadaća menadžera jest donošenje poslovnih odluka. Bez obzira o kojoj se vrsti odluka radi njihov konačni cilj jest osigurati optimalno poslovanje i ostvarivanje dobiti te budući rast i razvoj poduzeća. Rizik takvih odluka ne dopušta njihovo donošenje samo na intuiciji, već traži pouzdane i vjerodostojne informacije i promišljene aktivnosti kojima će osigurati ostvarivanje navedenih ciljeva. Među inima najvažniju aktivnost menadžera čini budžetiranje koje predstavlja temelj poslovnog planiranja i menadžerske kontrole nad poslovnim procesima i rezultatima poslovanja. S obzirom na vremenski rok planiranje se dijeli na dugoročno i kratkoročno. Prvim se obično na vrijeme duže od tri ili više godina utvrđuju strateški ciljevi zajedno s okvirnom sredstvima, širim uputama i aktivnostima njihova postizanja, dok se drugim kojeg nazivamo master budžet ili glavni poslovni plan obuhvaća razdoblje od jedne godine ili kraće razdoblje s preciznijim poslovnim ciljevima i detaljnijim sredstvima i aktivnostima kojima ih se namjerava realizirati. Master budžet predstavlja skup pojedinačnih budžeta dijelova, odnosno procesa u poduzeću koji zajedno čine sinergiju planiranih aktivnosti budućeg poslovanja poduzeća. Primjereno veličini poduzeća i prirodi njegova poslovanja razlikujemo master budžet proizvodnog i trgovačkog poduzeća. Međutim, u oba slučaja planiranje kao proces primjereno obuhvaća pripreme za planiranje, definiranje ciljeva, izradu i prihvaćanje pplan te kontrolu i analizu provedbe plana. Ovaj je rad posvećen središnjem dijelu planiranja, odnosno izradi master budžeta koji kao glavni poslovni plan obuhvaća operativni budžet i financijski budžet svih poslovnih aktivnosti proizvodnog poduzeća u razdoblju od jedne godine. Kao takav on predstavlja odgovor na tržišne izazove, neizvjesnosti i rizike poslovanja. Jednostavnošću prikaza posebno je prilagođen za potrebe malih poduzeća koja čine većinu gospodarskih subjekata u Republici Hrvatskoj. Cilj je rada ukazati na značaj master budžeta i prezentirati cjeloviti model poslovnog plana proizvodnog poduzeća i menadžerske kontrole nad svim poslovnim procesima. Također, cilj rada jest prezentirati obrazac prema kojem se u svakom poduzeću, od najmanjih do onih velikih, može sačiniti vlastiti godišnji master budžet i tako osigurati sigurnost $i$ kontrola svih poslovnih procesa poduzeća, a time uspješno poslovanje, dobit te rast $i$ razvoj poduzeća. U radu se na primjeren način koriste tehnike i metode analize $i$ sinteze, kao i metode planiranja. Kao izvori podataka koriste se vlastiti izvori, a od sekundarnih izvora koristi se stručna i znanstvena literatura.

Ključne riječi: master budžet; glavni poslovni plan; operativni budžet; financijski budžet 


\section{UVOD}

Polaznu osnovu u izučavanju ove problematike čini pretpostavka da je poduzeće poslovno financijski sustav u kojem menadžeri svakodnevno donose odluke kojima utječu na pribavljanje, kretanje i alokaciju financijskih i drugih resursa za optimalno tekuće poslovanje i razvoj poduzeća. Da bi tu svoju ulogu uspješno realizirali potrebno je planiranje u poduzeću, kojim se sprovodi, upravlja i usmjerava poslovna politika poduzeća. Međutim, planiranje bez kontrole ne može biti pa je stoga glavna aktivnost menadžera u procesu donošenja poslovnih odluka upravo planiranje i kontrola. Četiri su ključna pitanja planiranja u poduzeću: (1) informacije, (2) ciljevi i sadržaj planiranja, (3) organizacija i (4) kontrola. Informacije za planiranje moraju biti pravovremene, točne i pouzdane, a trebaju sadržavati i mogućnosti alternativa u planiranju. Izvori informacija mogu biti vanjski poput tržišta, statistike i sl. te unutarnji od raznih službi poput prodaje, proizvodnje, a posebice računovodstva i dr. Ciljevi i sadržaj planiranja mogu biti različiti, no predmet ovog rada jest poslovni plan ili glavni poslovni plan ili master budžet koji obuhvaća sve poslovne aktivnosti poduzeća s preciznijim poslovnim ciljevima i detaljnijim sredstvima i aktivnostima kojima ih se namjerava realizirati u tijeku jedne godine, a sastoji se od operativnog plana i financijskog plana. Određivanje ciljeva poduzeća i njegovih centara odgovornosti čine ključnu aktivnost planiranja. Organizacija planiranja ovisi o brojnim čimbenicima poput veličine poduzeća, djalatnosti poduzeća, složenosti organizacije poduzeća, procedurama donošenja odluka i sl. Poslovi planiranja mogu se obavljati u različitim organizacijskim oblicima službe planiranja: centralizirano, decentralizirano i/ili mješovito. „Bez obzira na koji je način organizirana služba planiranja u poduzeću, poslovima planiranja u poduzeću bave se svi sektori i službe u poduzeću, no ti poslovi su razni i specifični i uglavnom odgovaraju djelokrugu poslovanja pojedinih sektora. Svi poslovi planiranja i pojedini planovi koji se donose u pojedinim sektorima u poduzeću, moraju biti u skladu sa samostalnim planom poduzeća" (Grupa autora, 1965,540). Računovodstvene službe poduzeća obuhvaćaju i poslove planiranja i kontrole koji su definirani kao upravljačko računovodstvo, koje pruža informacije menadžerima za odlučivanje i upravljanje i u kojem se organizacijski odvijaju aktivnosti planiranja i kontrole. Kontrola je nerazdvojiva aktivnost planiranja. Ona podrazumijeva prikupljanje informacija o ostvarenim rezultatima, njihovu usporedbi s planiranim, analizu odstupanja te poduzimanje korektivnih aktivnosti. Cilj je ovog rada ukazati na značaj master budžeta i prezentirati cijeloviti model poslovnog plana proizvodnog poduzeća i menadžerske kontrole nad svim poslovnim procesima te pokazati postupak izrade poslovnog plana, pri čemu je pristup univerzalan, ali s obzirom na obuhvat smatramo ga najprimjenjivijim za mikro i mala poduzeća. Temeljne hipoteze rada su: (1) poslovnim planom definiraju se ciljevi poduzeća, pretpostavke i instrumenti njihove realizacije u funkciji sigurnijeg poslovanja, (2) upravljačkim odlukama realiziraju se ciljevi poslovnog plana i (3) praćenjem ostvarenih rezultata i usporednom analizom s planiranim ciljevima osigurava se poduzimanje korektivnih mjera. Primarno istraživanje autora obuhvaća financijsku analizu i kreiranje pretpostavaka planiranja, dok su sekundarna istraživanja obuhvatila relevantnu znanstvenu i stručnu literaturu za postavljanje okvira istraživanja. Metode rada obuhvaćaju primjenu analitičkih i planskih metoda i tehnika, a dobiveni rezultati su prikazani u prezentiranim tablicama s komentarima i zaključcima. 


\section{BUDŽETIRANJE KAO INSTRUMENT PLANIRANJA I KONTROLE}

Planiranje je dio strategije poslovnih subjekata, a s obzirom na vremenski kriterij uključujući kvantificiranje ciljeva, uobičajeno se dijeli na dugoročno i kratkoročno. Strategija općenito određuje kako poslovni subjekt, sukladno prilikama na tržištu koristiti svoje sposobnosti u svrhu ispunjavanja ciljeva. Strategija uključuje više pitanja, kao što su: (a) koji su ciljevi poslovnog subjekta, (b) koja su tržišta subjekta, (c) na koji način poslovni subjekt djeluje na gospodarstvo, industriju i konkurenciju, (d) koji oblici organizacije i financijske strukture najbolje odgovaraju poslovnom subjektu i (e) koji su rizici alternativnih strategijate koji je rezervni plan subjekta ako željeni plan ne uspije. Planiranje kompanije dugoročno i kratkoročno je dio strategije. Strategija definira planove, ali i planovi redefiniraju strategiju kompanije (Grupa autora, 2011, 267).

Dugoročno planiranje povezano je sa strateškim planiranjem na vrijeme duže od jedne godine i na globalnoj razini se bavi definiranjem dugoročnih ciljeva poduzeća, preispitivanjem okruženja i potrebnih resursa i najčešće povezivanjem strateških planova s dugoročnim financijskim planiranjem. Za razliku od dugoročnog, kratkoročno planiranje uobičajeno se odnosi na razdoblje jedne poslovne godine ili kraća razdoblja tijekom godine (mjesece ili tromjesečja). Kratkoročni plan je u funkciji dugoročnog plana, ali samo za godinu dana unaprijed te su zbog kraćeg vremenskog razdoblja na koje se odnose kratkoročni planovi puno precizniji i detaljniji (Grupa autora, 2015, 312).

Prema M. Hladiki važnost i korist od aktivnosti planiranja ogledaju se u osiguravanju podrške i usmjeravanju rasta i razvoja poduzeća budući da su u poslovnom planu sadržane odluke o korištemnju materijalnih, ljudskih i financijskih resursa poduzeća. poduzeće koje nema poslovni plan, zapravo nema ni svrhu ni ciljeve postojanja niti može učinkovito koristiti raspoložive resurse. Glavni menadžment koristi glavni poslovni plan za analizu djelotvornosti, odnosno sposobnosti ispunjenja poslovnih ciljeva, za analizu odstupanja između planiranog i ostvarenog kao i za eliminaciju odstupanja. Na temelju usporedbe između planiranih i ostvarenih veličina ocijenjuje se efikasnost menadžmenta poduzeća (Grupa autora, 2015, 316).

U nastavku ovog rada fokusirani smo na kratkoročno planiranje, odnosno budžetiranje za razdoblje od jedne godine, a to je glavni poslovni plan ili kako ga se još naziva poslovni plan odnosno master budžet, na razini cijeline i pojedinih dijelova poduzeća. U našoj ekonomskoj praksi podjednako se koriste obje inačice, pa ćemo ih u nastavku ovog rada također jednoznačno koristiti. Međutim, posebno treba istaknuti da planiranje i budžetiranje nisu sinonimi. Naime budžet (proračun) jest dio poslovnog plana, ali konačna namjera budžetiranja je opskrbljivanje menadžerskog informacijskog sustava izvješćima stvarnih perfomanci nasuprot planiranih performanci i permanentno uspostavljanje ravnoteže između izvora kapitala i trošenja u odnosu na varijacije od planiranih perfomanci. On je, dakle, temelj za raspodjelu kapitala i kontrolu njegove upotrebe u smislu sistematičnog i racionalnog ponašanja za postizanje sigurnijih i boljih rezultat (Belak, V., 1975, 175). 


\subsection{Pojam poslovnog plana poduzeća}

Sam izraz glavni poslovni plan, odnosno glavni plan govori da je riječ o izuzetno važnom dokumentu od posebnog značaja za poduzeće. On čini okosnicu pokretanja, financiranja, organizacije, vođenja i kontrole poslovanja i rezultata poslovanja. Gulin D. navodi da je pojam glavni poslovni plana engleskog podrijetla, kao sastavnica dviju riječi, "master" što u hrvatskom znači glavni, ukupan i sl. te „budget" što znači proračun (Grupa autora, 2011, 269.). Dakle, riječ je o glavnom proračunu, slijedom čega u domaćoj terminologiji koristimo i izraze poslovni plan ili master budžet, kao i izraze poslovno planiranje i budžetiranje. Master budžet sveobuhvatan je budžet za određeno vremensko razdoblje sastavljen od više međusobno povezanih dijelova operativnih i financijskih planova usmjerenih postizanju strateških ciljeva poduzeća za budžetsko razdoblje. Budžet je temeljni dio poslovnog planiranja i menadžerske kontrole. Budžetiranje nije zamišljeno kao druga funkcija knjigovodstvene discipline nego je uređeno kao tehnika raspodjele izvora kapitala i koordiniranja menadžerskih aktivnosti u cilju postizanja optimalnih ukupnih rezultata (Belak V., 1995, 175.).

\subsection{Ciljevi poslovnog plana}

Svrha poslovnog plana jest definirati ciljeve poduzeća, odabrati plansku politiku usklađenu s ciljevima poduzeća te definirati način i oblik kontrole kao i ispravljanja ili potvrđivanja planskih politika usklađenih s ciljevima poduzeća. Posebno treba istaknuti da planiranje $i$ budžetiranje nisu sinonimi. Naime budžet (proračun) jest dio poslovnog plana, ali konačna namjera budžetiranja je opskrbljivanje menadžerskog informacijskog sustava izvješćima stvarnih perfomanci nasuprot planiranih perfomanci i permanentno uspostavljanje ravnoteže između izvora kapitala i trošenja u odnosu na varijacije od planiranih perfomanci (Belak V., 1995, 175.).

Pristup planiranju razlikuje se u velikim poduzećima, posebice ako su to dionička društva, od prakse u malim poduzećima. Za razliku od velikih poduzeća gdje postoji spoznaja o važnosti planiranja, planiranjem se bavi posebno tijelo (komisija, odbor, sektor) čiji rad koordinira menadžer, u malim poduzećima planiranjem se obično bavi stručna služba računovodstva pod izravnim rukovodstvom menadžera.

Poslovni planovi imaju svoje dobre i loše strane. Obično se među dobrim stranama ističu: postojanje smjernica za ostvarivanje ciljeva, koordinacija aktivnosti, motivacija zaposlenih i postojanje kriterija procjene uspješnosti. Međutim, poslovni planovi mogu imati i nedostatke kao što su: ograničavajuće djelovanje, demotiviranost zaposlenih ili nedostatak kontrole troškova. Hoće li se i u kojoj mjeri pozitivne i negativne strane poslovnih planova pojaviti ovisi od više čimbenika. Tako, na primjer, ako su u postupku donošenja poslovnih planova učestovali zaposlenici, zbog osjećaja participacije u njihovu donošenju jačat će i motiviranost zaposlenika za njihovom realizacijom. Nasuprot tome, u slučaju ako su planovi što ih je postavio menadžer nerealni, to će demoralizirati zaposlenike u njihovu angažmanu. Isto tako, ako priopćeni planovi nisu praćeni stimulacijama za njihovo ostvarivanje, izostat će stvaralačka inicijativa zaposlenika i poticaj za kontrolom troškova. 


\subsection{Sadržaj poslovnog plana}

Poslovni plan se izrađuje za jednu obračunsku poslovnu godinu. Glavni poslovni plan obično se sastoji od većeg broja međusobno povezanih poslovnih planova odnosno budžeta, koji zajedno sumiraju planirane aktivnosti budućeg poslovanja poduzetnika. Sadržaj i elementi glavnog poslovnog plana variraju ovisno o veličini, vrsti i djelatnosti poduzeća. Međutim, standardni sadržaj poslovnog plana (budžeta) čine: (1) operativni plan i (b) financijski plan. Oni odražavaju poslovne i financijske odluke menadžera za sljedeću poslovnu godinu.

Operativni plan (budžet) sastoji se od prognoze prodaje, rasporeda proizvodnje, proračuna troškova proizvodnje, proračuna općih administrativnih i prodajnih troškova i proračuna dobitka. Pojedinačno su to sljedeći međusobno povezani planovi: (1) plan prodaje, (2) plan proizvodnje, (3) plan nabave materijala, (4) plan trošenja direktnog materijala, (5) plan direktnog rada, (6) plan općih troškova proizvodnje, (7) plan troškova prodanih proizvoda, (8) plan troškova prodaje, (9) plan administrativnih troškova i (10) planirani izvještaj o dobiti.

Financijski plan primarno uključuje planiranje novca i novčanih ekvivalenata i planiranje bilance te kapitalni proračun koji se javlja i kao zaseban proračun i obuhvaća proces procjene i planiranja investiranja u aktivu društva. Budući da smo fokusirani na poslovni plan mikro i malog poduzeća unutar jednogodišnjeg razdoblja, u ovom radu ćemo uključiti samo: (a) planirani novčani proračun i (b) plansku bilancu.

\section{PRIPREMA POSLOVNOG PLANA}

Izrada poslovnog plana započinje pribavljanjem dokumentacijske podloge koju čine: (1) informacije iz temeljnih financijskih izvještaja prethodnog razdoblja i (2) procjene menadžmenta za nadolazeće razdoblje koje se kvantificira po svakom segmentu procesa rada u poduzeću, a završava izradom master budžeta.

Menadžersko i financijsko računovodstvo osiguravaju podatke o početnom stanju imovine, kapitala i obveza te ostvarenim troškovima u prethodnom obračunskom razdoblju i to zasebno podaci o troškovima koji se obračunavaju po proizvodima (izravni troškovi) od općih administrativnih i prodajnih (režijski ili neizravni) troškova koji se obračunavaju kao troškovi razdoblja i u postupku planiranja se raspoređuju primjenom odgovarajućih kriterija na nositelja troškova. Konačno, za pripremu poslovnog plana od posebne su važnosti informacije o tržištu i mogućnostima prodaje, o čemu se procjene menadžera za nadolazeće razdoblje temelje na istraživanjima tržišta i prognoziranim mogućnostima prodaje.

Polazni dokument u pristupu sastavljanja poslovnog plana jest bilanca, kao temeljna informacijska osnova za izradu poslovnog plana. U primjeru koji je izložen pretpostavlja se izrada godišnjeg poslovnog plana raščlanjenog po tromjesečjima jedne obračunske poslovne godine. Prikazani se poslovni plan odnosi na manje proizvodno društvo, bilanca kojeg na dan 31. prosinca 20x1. godine sadrži sljedeće inofomacije. 
Tablica 1. Bilanca na dan 31.12. 20x1. kn

\begin{tabular}{|c|c|}
\hline Opis & 31.12. $20 \times 1$. \\
\hline Dugotrajna imovina & 200.000 \\
\hline Nekretnine & 200.000 \\
\hline Oprema & 100.000 \\
\hline Amortizacija & $(100.000)$ \\
\hline Kratkotrajna imovina & 210.000 \\
\hline Zalihe materijala & 9.000 \\
\hline Zalihe proizvoda & 30.000 \\
\hline Potraživanja & 90.000 \\
\hline Novac & 81.000 \\
\hline UKUPNO AKTIVA & 410.000 \\
\hline Kapital i rezerve & 370.000 \\
\hline Upisani temeljni kapital & 300.000 \\
\hline Zadržana dobit & 70.000 \\
\hline Dobit razdoblja & 0 \\
\hline Dugoročne obveze & 0 \\
\hline Kratkoročne obveze & 40.000 \\
\hline Dobavljači & 40.000 \\
\hline UKUPNO PASIVA & 410.000 \\
\hline
\end{tabular}

Izvor: vlastiti rad autora

\section{SASTAVLJANJE OPERATIVNOG PLANA}

Proces operativnog godišnjeg planiranja temelji se na planu prodaje koji se izrađuje na osnovi marketinških prognoza i procjene troškova proizvodnje, a završava izradom master budžeta operativnih planova menadžmenta za budžetsko razdoblje. U ovom je primjeru temeljna pretpostavka da poduzeće proizvodi jednu vrsta proizvoda $A$, zbog čega troši jednu vrstu sirovina kao direktni materijal. Procjenu utroška materijala i svih drugih resursa, kao i informacije s procjenama tržišta menadžment osigurava službi računovodstva koja u malom poduzeću sastavlja poslovni plan. Nastavno su pri izradi operativnog plana (budžeta) sve pretpostavke za njegovu izradu prezentirane po sastavnicama operativnog plana.

\subsection{Plan (budžet) prodaje}

Temelji se na iskustvima iz prethodnog razdoblja i provedenom istraživanju tržišta. Predviđeno je da će se tokom poslovne godine po cijeni od 10,00 kuna za jedinici proizvoda prodati sljedeće količine proizvoda:

- prvo tromjesečje 30.000 komada,

- drugo tromjesečje 40.000 komada, 
- $\quad$ treće tromjesečje 50.000 komada

- četvrto tromjesečje 60.000 komada i

Metodološki izrada plana (budžeta) prodaje i s njim povezani plan novčanih primitaka može se ilustrirati na sljedeći način:

planirana količina

x jedinična prodajna cijena

= prihodi od prodaje

Tablica 2. Budžet prodaje

\begin{tabular}{|l|c|c|c|c|c|}
\hline Opis & I & II & III & IV & Ukupno \\
\hline Plan prodaje (kom) & 30.000 & 40.000 & 50.000 & 60.000 & 180.000 \\
\hline Planska PC, kn & 10,00 & 10,00 & 10,00 & 10,00 & 10,00 \\
\hline Ukupno prodaja (kn) & 300.000 & 400.000 & 500.000 & 600.000 & 1.800 .000 \\
\hline
\end{tabular}

Izvor: vlastiti rad autora

Procjena prodaje sadržajno obuhvaća i plan naplate potraživanja od kupaca. Predviđa se naplata potraživanja sljedećom dinamikom: $70 \%$ u istom tromjesečju i $30 \%$ u sljedećem tromjesečju. Također, u prvom se tromjesečju predviđa naplata potraživanja iz prethodne godine u iznosu 90.000 kuna.

Tablica 3. Plan naplate potraživanja

\begin{tabular}{|l|c|c|c|c|c|}
\hline Opis & I & II & III & IV & Ukupno \\
\hline Stara potraživanja & 90.000 & - & - & - & 90.000 \\
\hline Primici I. tromjesečje & 210.000 & 90.000 & - & - & 300.000 \\
\hline Primici II. tromjesečje & - & 280.000 & 120.000 & - & 400.000 \\
\hline Primici III. tromjesečje & - & - & 350.000 & 150.000 & 500.000 \\
\hline Primici IV. tromjesečje & - & - & - & 420.000 & 420.000 \\
\hline Ukupno naplata (kn) & 300.000 & 370.000 & 470.000 & 570.000 & 1.710 .000 \\
\hline
\end{tabular}

Izvor: vlastiti rad autora

\subsection{Plan proizvodnje}

Treba osigurati redovito snabdjevanje tržišta prema planiranoj dinamici prodaje i željeno stanje zaliha gotovih proizvoda na kraju svakog tromjesečja u godini. Pretpostavljene polazne veličine su sljedeće:

- početne zalihe iz prethodne godine iznose 6000 komada vrijednosti 30.000 kuna,

- željeno stanje zaliha krajem razdoblja jest 20\% plana prodaje sljedećeg razdoblja,

- planirane zalihe na kraju razdoblja su 9000 komada proizvoda

- za obračun utroška zaliha u primjeni je FIFO metoda 
Metodološki izrada plana proizvodnje može se ilustrirati na sljedeći način:

Planirana prodaja

+ planirane konačne zalihe

- početne zalihe

= potrebna proizvodnja

Tablica 4. Plan proizvodnje gotovih proizvoda

\begin{tabular}{|l|c|c|c|c|c|}
\hline Opis & I & II & III & IV & Ukupno \\
\hline Plan prodaje (kom) & 30.000 & 40.000 & 50.000 & 60.000 & 180.000 \\
\hline Plan konačnih zaliha & 8.000 & 10.000 & 12.000 & 9.000 & 9.000 \\
\hline Ukupno potrebna količina & 38.000 & 50.000 & 62.000 & 69.000 & 189.000 \\
\hline Početno stanje zaliha & $(6.000)$ & $(8.000)$ & $(10.000)$ & $(12.000)$ & $(6.000)$ \\
\hline Potrebna proizvodnja (kom) & 32.000 & 42.000 & 52.000 & 57.000 & 183.000 \\
\hline
\end{tabular}

Izvor: vlastiti rad autora

\subsection{Plan (budžet) troškova direktnog materijala}

Polazi od utroška materijala po jedinici proivoda (normativ utroška) u iznosu od 3 kg za jedinicu proizvoda. Ostale pretpostavljene informacije su sljedeće:

- $\quad$ početno stanje zaliha je 9000 kg vrijednosti 9.000,00 kuna (1,00 kn/jed)

- planirano stanje zaliha po kvartalima su $10 \%$ potreba sljedećeg tromjesečja,

- planirano stanje zaliha zadnjeg tromjesečja iznose 19.000 kilograma

- troškovi nabave po jedinici iznose $1,00 \mathrm{kn} / \mathrm{kg}$

Metodološki se plan (budžet) nabave direktnog materijala za potrebe proizvodnje gotovih proizvoda može ilustrirati na sljedeći način:

$$
\text { plan proizvodnje (kom) }
$$

\section{$\underline{x \text { normativ utroška materijala }(\mathrm{kg})}$}

$=$ plan potrebnog materijala $(\mathrm{kg})$

+ plan konačnih zaliha materijala $(\mathrm{kg})$

- početne zalihe materijala (kg)

= plan nabave materijala $(\mathrm{kg})$

$\underline{x}$ troškovi nabave po jedinici

= nabavna vrijednost materijala 
Tablica 5. Plan (budžet) nabave direktnog materijala

\begin{tabular}{|l|c|c|c|c|c|}
\hline Opis & I & II & III & IV & Ukupno \\
\hline Planirana proizvodnje (kom) & 32.000 & 42.000 & 52.000 & 57.000 & 183.000 \\
\hline Količina materijala po jedinici & 3 & 3 & 3 & 3 & 3 \\
\hline Ukupna količina za proizvodnju & 96.000 & 126.000 & 156.000 & 171.000 & 549.000 \\
\hline Željeno stanje konačnih zaliha & 12.600 & 15.600 & 17.100 & 19.000 & 19.000 \\
\hline Ukupno potrebna količina & 108.600 & 161.600 & 173.100 & 190.000 & 568.000 \\
\hline Početno stanje zalihe & $(9.000)$ & $(12.600)$ & $(15.600)$ & $(17.100)$ & $(9.000)$ \\
\hline Ukupno potrebna nabava (kg) & 99.600 & 149.000 & 157.500 & 172.900 & 559.000 \\
\hline Troškovi nabave po jedinici & 1,00 & 1,00 & 1,00 & 1,00 & \\
\hline Nabavna vrijednost & 99.600 & 149.000 & 157.500 & 172.900 & 559.000 \\
\hline
\end{tabular}

Izvor: vlastiti rad autora

Procjena nabave direktnog materijala sadržajno obuhvaća i dinamiku plaćanja obveza prema dobavljačima. Planira se plaćanje obveza prema dobavljačima sljedećom dogovorenom dinamikom: 50\% u razdoblju nabavke i 50\% u sljedećem razdoblju. Također, u prvom se tromjesečju predviđa plaćanje obveze iz prethodne godine u iznosu 40.000 kuna.

Tablica 6. Plan novčanih izdataka za direktni materijal

\begin{tabular}{|l|c|c|c|c|c|}
\hline Opis & I & II & III & IV & Ukupno \\
\hline Nabava iz prethodne godine & 40.000 & - & - & - & 40.000 \\
\hline Izdaci u I tromjesečju & 49.800 & 49.800 & - & - & 99.600 \\
\hline Izdaci u II. tromjesečju & - & 74.500 & 74.500 & - & 149.000 \\
\hline Izdaci u III. tromjesečju & - & - & 78.750 & 78.750 & 157.500 \\
\hline Izdaci u IV tromjesečju & - & - & - & 86.450 & 86.450 \\
\hline Ukupno & 89.800 & 124.300 & 153.250 & 165.200 & 532.550 \\
\hline
\end{tabular}

Izvor: vlastiti rad autora

Temeljem planirane proizvodnje gotovih proizvoda i planirane nabave direktnog materijala, sastavlja se budžet troškova direktnog materijala. 
Tablica 7. Budžet troškova direktnog materijala

\begin{tabular}{|l|c|c|c|c|c|}
\hline Opis & I & II & III & IV & Ukupno \\
\hline Potrebna količina za proizvodnju & 96.000 & 126.000 & 156.000 & 171.000 & 549.000 \\
\hline Početno stanje zaliha & 9.000 & 12.600 & 15.600 & 17.100 & 9.000 \\
\hline Troškovi nabave po jedinici & 1,00 & 1,00 & 1,00 & 1,00 & 1.000 \\
\hline NV početnih zaliha & 9.000 & 12.600 & 15.600 & 17.100 & 9.000 \\
\hline Troškovi nabave zaliha & 99.600 & 149.000 & 157.500 & 172.900 & 559.000 \\
\hline Ukupni troškovi zaliha & 108.600 & 161.600 & 173.100 & 190.000 & 568.000 \\
\hline Željeno konačno stanje zaliha & 12.600 & 15.600 & 17.100 & 19.000 & 19.000 \\
\hline Troškovi nabave po jedinici & 1,00 & 1,00 & 1,00 & 1,00 & 1,00 \\
\hline NV konačnih zaliha & $(12.600)$ & $(15.600)$ & $(17.100)$ & $(19.000)$ & $(19.000)$ \\
\hline Vrijednost utrošenog materijala & 96.000 & 146.000 & 156.000 & 171.000 & 549.000 \\
\hline
\end{tabular}

Izvor: vlastiti rad autora

\subsection{Plan (budžet) troškova direktnog rada}

Budžet troškova direktnog rada temelji se na planu proizvodnje. Ukupna količina i direktnog rada utvrđuju se prema normativima utroška rada po jedinici proizvoda, a vrijednost, odnosno troškovi rada, umnoškom planiranog utroška rada s planiranom cijenom sata direktnog rada za jedinicu proizvoda. Metodološki se plan (budžet) troškova direktnog rada utvrđuje prema sljedećem obrascu.

Planirana količina proizvoda

$\underline{x}$ potrebni sati direktnog rada po jedinici proizvoda

= ukupno planirani sati direktnog rada

$\underline{x \text { cijena sata direktnog rada }}$

= trošak direktnog rada

Tablica 8. Plan (budžet) troškova direktnog rada

\begin{tabular}{|l|c|c|c|c|c|}
\hline Opis & I & II & III & IV & Ukupno \\
\hline Plan proizvodnje (kom) & 32.000 & 42.000 & 52.000 & 57.000 & 183.000 \\
\hline Normativ sati direktnog rada & 0,1 & 0,1 & 0,1 & 0,1 & 0,1 \\
\hline Ukupno sati direktnog rada & 3.200 & 4.200 & 5.200 & 5.700 & 18.300 \\
\hline Cijena sata rada & 20,00 & 20,00 & 20,00 & 20,00 & 20,00 \\
\hline Ukupno trošak direktnog rada & 64.000 & 84.000 & 104.000 & 114.000 & 366.000 \\
\hline
\end{tabular}

Izvor: vlastiti rad autora 


\subsection{Plan (budžet) općih troškova proizvodnje}

Opći (indirektni) troškovi proizvodnje imaju svoju fiksni i varijabilni dio. Stoga je pri izradi plana (budžeta) općih troškova proizvodnje potrebno razdvojiti i zasebno planirati fiksnu i varijabilnu komponentu općih troškova proizvodnje.

Fiksni opći troškovi proizvodnje, poput amortizacije i sl. uglavnom ne ovise od stupnja iskorištenja kapaciteta pa se njihov budžetirani iznos obično planira na temelju procjena, što zbog visine tih troškova zahtjeva oprezan pristup u procjenama.

Za razliku od toga, varijabilni dio općih troškova proizvodnje utvrđuje se i raspoređuje prema unaprijed utvrđenim kriterijima i stopama rasporeda, koji najprimjerenije odražavaju utrošak indirektnih resursa u proizvodnji pojedinih proizvoda. Naprimjer, u slučaju radno intezivne djelatnosti uobičajeno se raspodjela vrši na osnovu sati direktnog rada, a suprotno tome kod kapitalno intezivne proizvodnje primjereno je koristiti utroške sati strojnog rada.

Slijedom navedenog, metodološki se plan (budžet) općih troškova proizvodnje utvrđuje prema sljedećem obrascu.

Planirana baza rasporeda varijabilnih općih troškova proizvodnje

$\underline{x \text { stopa rasporeda varijabilnih općih troškova proizvodnje }}$

=ukupni varijabilni troškovi proizvodnje

+fiksni opći troškovi proizvodnje

=ukupni opći troškovi proizvodnje

Tablica 9. Budžet općih troškova proizvodnje

\begin{tabular}{|l|c|c|c|c|c|}
\hline Opis & I & II & III & IV & Ukupno \\
\hline Plan sat direktnog rada & 3.200 & 4.200 & 5.200 & 5.700 & 18.300 \\
\hline Cijena po satu rada & 0,50 & 0,50 & 0,50 & 0,50 & 0,50 \\
\hline 1. Varijabilni OTP & 1.600 & 2.100 & 2.600 & 2.850 & 9.150 \\
\hline 2. Fiksni OTP & 20.000 & 20.000 & 20.000 & 20.000 & 80.000 \\
\hline Ukupni OTP (1+2) & 21.600 & 22.100 & 22.600 & 22.850 & 89.150 \\
\hline
\end{tabular}

Izvor: vlastiti rad autora

S budžetom općih troškova proizvodnje potrebno je planirati i dinamiku plaćanja tih troškova. Pri planiranju plaćanja izuzima se planirani trošak amortizacije jer s navedenim troškom nema i odljeva novca na ime plaćanja. 
Tablica 10. Plaćanje općih troškova proizvodnje

\begin{tabular}{|l|c|c|c|c|c|}
\hline Opis & I & II & III & IV & Ukupno \\
\hline Ukupni OTP & 21.600 & 22.100 & 22.600 & 22.850 & 89.150 \\
\hline Amortizacija & $(5.000)$ & $(5.000)$ & $(5.000)$ & $(5.000)$ & $(20.000)$ \\
\hline Potrebna plaćanja & 16.600 & 17.100 & 17.600 & 17.850 & 69.150 \\
\hline
\end{tabular}

Izvor: vlastiti rad autora

Planiranjem troškova proizvodnje, dakle direktnih troškova materijala i troškova rada te općih troškova proizvodnje, obuhvaćeni su oni troškovi koji kalkulacijom daju proizvođačku cijenu. Slijedom toga sačinjen je planski obračun troškova konačnih zaliha gotovih proizvoda i obračun troškova prodanih gotovih proizvoda. Dok prvi predstavlja kontrolni obračun vrijednosti konačnih zaliha i kao takav čini bilančnu poziciju na kraju planskog razdoblja, drugi predstavlja prikaz proizvodnih troškova prodanih proizvoda i sastavni je dio računa dobiti i gubitka. Za obračun su korišteni podaci iz prethodnih tablica planiranja prodaje, proizvodnje i troškova proizvodnje.

Tablica 11. Obračun troškova konačnih zaliha gotovih proizvoda

\begin{tabular}{|l|c|c|c|c|c|}
\hline Opis & I & II & III & IV & Ukupno \\
\hline Direktni materijal & 96.000 & 126.000 & 156.000 & 171.000 & 549.000 \\
\hline Direktni rad & 64.000 & 84.000 & 104.000 & 114.000 & 366.000 \\
\hline Opći troškovi proizvodnje & 21.600 & 22.100 & 22.600 & 22.850 & 89.150 \\
\hline Ukupni troškovi proizvodnje & 181.600 & 232.100 & 282.600 & 307.850 & 1.004 .150 \\
\hline Planirana proizvodnja & 32.000 & 42.000 & 52.000 & 57.000 & 183.000 \\
\hline Planirani trošak po jedinici & 5,675 & 5,526 & 5,435 & 5,401 & \\
\hline Željeno konačno stanje & 8.000 & 10.000 & 12.000 & 9.000 & \\
\hline Vrijednost konačnih zaliha & 45.400 & 55.260 & 65.220 & 48.609 & \\
\hline
\end{tabular}

Izvor: vlastiti rad autora

Tablica 12. Obračun troškova prodanih proizvoda

\begin{tabular}{|l|c|c|c|c|c|}
\hline Opis & I & II & III & IV & Ukupno \\
\hline Ukupni troškovi proizvodnje & 181.600 & 232.100 & 282.600 & 307.850 & 1.004 .150 \\
\hline Vrijednost početnih zaliha & 30.000 & 45.400 & 55.260 & 65.220 & 30.000 \\
\hline Vrijednost zaliha za prodaju & 211.600 & 277.500 & 337.860 & 373.070 & 1.034 .150 \\
\hline Vrijednost konačnih zaliha & $(45.400)$ & $(55.260)$ & $(65.220)$ & $(48.609)$ & (48.609) \\
\hline Troškovi prodanih proizvoda & 166.200 & 222.240 & 272.640 & 324.461 & 985.541 \\
\hline
\end{tabular}

Izvor: vlastiti rad autora 


\subsection{Plan (budžet) općih troškova uprave i prodaje}

Za razliku od općih troškova proizvodnje koji čine sastavni dio kalkulacije proizvodne cijene proizvoda, opći troškovi uprave i pradaje (OTUP), koje uobičajeno nazivamo režijskim troškovima, tretiraju se kao rashodi razdoblja, sastavni su dio kalkulacije cijene koštanja i izravno su obuhvaćeni u račun dobiti i gubitka u razdoblju u kojem su nastali. Metodološki se plan (budžet) općih troškova uprave i prodaje utvrđuje prema sljedećem obrascu.

Plan prodaje (količina)

$\underline{x}$ varijabilbni troškovi prodaje po jedinici proizvoda

=varijabilni troškovi prodaje

+fiksni troškovi uprave

+fiksni troškovi prodaje

=ukupni troškovi uprave i prodaje

Tablica 13. Budžet općih troškova (rashoda) uprave i prodaje

\begin{tabular}{|l|c|c|c|c|c|}
\hline Opis & I & II & III & IV & Ukupno \\
\hline Plan prodaje & 30.000 & 40.000 & 50.000 & 60.000 & 180.000 \\
\hline VT po proizvodu & 0,50 & 0,50 & 0,50 & 0,50 & 0,50 \\
\hline 1. Varijabilni OTUP & $\mathbf{1 5 . 0 0 0}$ & $\mathbf{2 0 . 0 0 0}$ & $\mathbf{2 5 . 0 0 0}$ & $\mathbf{3 0 . 0 0 0}$ & $\mathbf{9 0 . 0 0 0}$ \\
\hline Marketing & 1.500 & 1.500 & 1.500 & 1.500 & 6.000 \\
\hline Osiguranje & 900 & 900 & 900 & 900 & 3.600 \\
\hline Plaće radnika uprave & 22.000 & 22.000 & 22.000 & 22.000 & 88.000 \\
\hline Porezi & 600 & 600 & 600 & 600 & 2.400 \\
\hline Najam & 1.000 & 1.000 & 1.000 & 1.000 & 4.000 \\
\hline 2. Fiksni OTP & $\mathbf{2 6 . 0 0 0}$ & $\mathbf{2 6 . 0 0 0}$ & $\mathbf{2 6 . 0 0 0}$ & $\mathbf{2 6 . 0 0 0}$ & $\mathbf{1 0 4 . 0 0 0}$ \\
\hline Ukupni OTP (1+2) & $\mathbf{4 1 . 0 0 0}$ & $\mathbf{4 6 . 0 0 0}$ & $\mathbf{5 1 . 0 0 0}$ & $\mathbf{5 6 . 0 0 0}$ & $\mathbf{1 9 4 . 0 0 0}$ \\
\hline
\end{tabular}

Izvor: vlastiti rad autora

S budžetom općih troškova uprave i prodaje potrebno je planirati i dinamiku plaćanja tih troškova. Pri planiranju plaćanja, izuzima se planirani trošak amortizacije jer s obračunatom amortizacijom nema odljeva novca na ime plaćanja.

Tablica 14. Plaćanje troškova uprave i prodaje

\begin{tabular}{|l|c|c|c|c|c|}
\hline Opis & I & II & III & IV & Ukupno \\
\hline Ukupni OTUP & 41.000 & 46.000 & 51.000 & 56.000 & 194.000 \\
\hline Amortizacija & $(10.000)$ & $(10.000)$ & $(10.000)$ & $(10.000)$ & $(40.000)$ \\
\hline Potrebna plaćanja & 31.000 & 36.000 & 41.000 & 46.000 & 154.000 \\
\hline
\end{tabular}

Izvor: vlastiti rad autora 


\subsection{Planiranje (budžetiranje) računa dobiti i gubitka}

Planiranjem računa dobiti i gubitka završni je dio operativnog plana. Naime, budžetiranjem općih troškova uprave i prodaje, odnosno režijskih rashoda, pored prethodno planiranih (budžetiranih) prihoda od prodaje gotovih proizvoda i budžetiranih direktnih i općih troškova proizvodnje, stvorena je pretpostavka da se pristupi planiranju (budžetiranju) računa dobiti i gubitka za plansko obračunsko razdoblje.

Sve potrebne pozicije za izradu planskog računa dobiti i gubitka preuzimaju se iz prethodno planiranih (budžetiranih) pozicija sastavnica ukupnog operativnog plana. Slijedom toga sačinili smo sljedeći planirani račun dobiti i gubitka.

Tablica 15. Budžetirani račun dobiti i gubitka

\begin{tabular}{|l|c|c|c|c|c|}
\hline Opis & I & II & III & IV & Ukupno \\
\hline Prihodi od prodaje & 300.000 & 400.000 & 500.000 & 600.000 & 1.800 .000 \\
\hline Troškovi prodanih proizvoda & 166.200 & 222.240 & 272.640 & 324.461 & 985.541 \\
\hline Bruto dobit & $\mathbf{1 3 3 . 8 0 0}$ & $\mathbf{1 7 7 . 7 6 0}$ & $\mathbf{2 2 7 . 3 6 0}$ & $\mathbf{2 7 5 . 5 3 9}$ & $\mathbf{8 1 4 . 4 5 9}$ \\
\hline Troškovi uprave i prodaje & 41.000 & 46.000 & 51.000 & 56.000 & 194.000 \\
\hline Dobit prije poreza & $\mathbf{9 2 . 8 0 0}$ & $\mathbf{1 3 1 . 7 6 0}$ & $\mathbf{1 7 6 . 3 6 0}$ & $\mathbf{2 1 9 . 5 3 9}$ & $\mathbf{6 2 0 . 4 5 9}$ \\
\hline Porez na dobit 12\% & 11.136 & 15.811 & 21.163 & 26.345 & 74.455 \\
\hline Dobit poslije poreza & $\mathbf{8 1 . 6 6 4}$ & $\mathbf{1 1 5 . 9 4 9}$ & $\mathbf{1 5 5 . 1 9 7}$ & $\mathbf{1 9 3 . 1 9 4}$ & $\mathbf{5 4 6 . 0 0 4}$ \\
\hline
\end{tabular}

Izvor: vlastiti rad autora

Vidljivo je da poduzetnik planira poslovanje u sljedećoj godini na način da mu postupno raste proizvodnja i promet, kao i poslovni prihodi s jedne i nešto sporijom stopom rastu rashodi, tako da je dinamički promatrano planirani financijski rezultat pozitivan, a dobit se tijekom godine po tromjesečjima postupno povećava. Pri obračunu poreza na dobit primjenjena je stopa poreza na dobit u iznosu $12 \%$, koliko je trenutno propisana porezna stopa za malog poduzetnika, a koji je predmetom našeg promatranja pri sastavljanju (budžetiranju) ovog poslovnog plana.

\section{SASTAVLJANJE FINANCIJSKOG PLANA}

Financijski plan obuhvaća primarno planiranje novca i novčanih ekvivalenata (novčani tok) i planiranje bilance te kapitalni proračun kao zasebni proračun koji obuhvaća planiranje (budžetiranje) investiranja u povećanje dugotrajne aktive. Ovim proračunom nisu obuhvaćena investicijska ulaganja pa stoga u nastavku sastavljanja financijskog plana obuhvaćamo samo budžetirani novčani proračun i proračunsku bilancu s usporednim podacima s početka tekuće godine. 


\subsection{Planiranje (budžetiranje) novčanog proračuna}

Pri planiranjuu (budžetiranju) novčanog proračuna polazi se od početnog stanja novca, a potom se ono dopunjava stvarnim tokovima novca i ekvivalenata novca ostvarenih kao priljevi, odnosno odljevi novca, temeljem planiranog poslovanja u planskoj obračunskoj godini. Metodološki se plan (budžet) općih novčanog proračuna utvrđuje prema sljedećem obrascu.

$$
\begin{gathered}
\begin{array}{c}
\text { Početni saldo novca } \\
\text { tplanirani novčani primici }
\end{array} \\
=\text { ukupno raspoloživi novac za financiranje } \\
\underline{\text { - ukupno planirani novčani izdaci }} \\
=\text { planirani višak (manjak) novca }
\end{gathered}
$$

Tablica 16. Budžetirani novčani proračun

\begin{tabular}{|l|c|c|c|c|c|}
\hline Opis & I & II & III & IV & Ukupno \\
\hline Početno stanje novca & $\mathbf{8 1 . 0 0 0}$ & $\mathbf{1 6 8 . 4 6 4}$ & $\mathbf{2 7 1 . 2 5 3}$ & $\mathbf{4 1 4 . 2 4 0}$ & $\mathbf{8 1 . 0 0 0}$ \\
\hline Novčani primici & & & & & \\
\hline - Naplata potraživanja & 300.000 & 370.000 & 470.000 & 570.000 & 1.710 .000 \\
\hline Ukupno raspoloživ novac & $\mathbf{3 8 1 . 0 0 0}$ & $\mathbf{5 3 8 . 4 6 4}$ & $\mathbf{7 4 1 . 2 5 3}$ & $\mathbf{9 8 4 . 2 4 0}$ & $\mathbf{1 . 7 9 1 . 0 0 0}$ \\
\hline Novčani izdaci & & & & & \\
\hline - Direktni materijal & 89.800 & 114.300 & 143.250 & 165.200 & 512.550 \\
\hline - Direktni rad & 64.000 & 84.000 & 104.000 & 114.000 & 366.000 \\
\hline - Opći troškovi proizvodnje & 16.600 & 17.100 & 17.600 & 17.850 & 69.150 \\
\hline - Troškovi uprave i prodaje & 31.000 & 36.000 & 41.000 & 46.000 & 154.000 \\
\hline - Porez na dobit & 11.136 & 15.811 & 21.163 & 26.345 & 74.455 \\
\hline Ukupno novčani odljevi & $\mathbf{2 1 2 . 5 3 6}$ & $\mathbf{2 6 7 . 2 1 1}$ & $\mathbf{3 2 7 . 0 1 3}$ & $\mathbf{3 6 9 . 3 9 5}$ & $\mathbf{1 . 1 7 6 . 1 5 5}$ \\
\hline Završno stanje & $\mathbf{1 6 8 . 4 6 4}$ & $\mathbf{2 7 1 . 2 5 3}$ & $\mathbf{4 1 4 . 2 4 0}$ & $\mathbf{6 1 4 . 8 4 5}$ & $\mathbf{6 1 4 . 8 4 5}$ \\
\hline
\end{tabular}

Izvor: vlastiti rad autora

Iz prethodne je tablice vidljivo da je početno stanje novca iznosilo 81.000,00 kuna, a potom su slijedom naplate potraživanja od prodaje gotovih proizvoda ostvareni primici u iznosu 1.710.000,00 kuna, od kojeg su iznosa odbijeni realizirani novčani izdaci u iznosu 1.176.155,00 kuna, nakon čega završno stanje novca iznosi 614.845,00 kuna. Navedena početna stanja i završna stanja novca kontrolno su vidljiva u početnoj i planiranoj bilanci.

\subsection{Planska bilanca}

Izradom planske bilance dovršava se proces sastavljanja financijskog plana. Njome su u konačnom prikazani rezultati koji proizlaze iz poslovnog plana, odnosno budžetiranja poslovanja poduzetnika. Prikazanim stanjem i strukturom bilance objedinjeni su rezultati poslovanja i njihov utjecaj na financijsko stanje poduzetnika. U našem je slučaju vidljivo, 
da je slijedom planskog (budžetiranog) poslovanja došlo do kvalitetnih promjena u horizontalnoj i vertikalnoj strukturi bilance.

Usporedbom planiranog s početnim stanjem bilance vidljivo je značajno povećanje aktive bilance. U strukturi tog povećanja, došlo je do smanjenja neto vrijednosti dugotrajne imovine, kao posljedica obračunate amortizacije i činjenice da se ne planiraju ulaganja u dugotrajnu imovinu. Međutim, značajno je povećana kratkotrajna imovina i to na svim pozicijama, kao posljedica planiranog rasta obima proizvodnje i prometa proizvoda te povećanih planiranih novčanih primitaka. Na strani pasive bilance, povećani su kapital i rezerve po osnovu planiranog povećanja dobiti tekućeg razdoblja, dugotročnih obveza nema, dok su kratkoročne obveze povećane ispodprosječnom stopom rasta pasive, $u$ razini nepodmirenih obveza prema dobavljačima.

Tablica 17. Bilanca na dan 31.12.20x2. godine kn

\begin{tabular}{|c|c|c|}
\hline Opis & 31.12. $20 \times 1$ & 31.12. $20 \times 2$ \\
\hline Dugotrajna imovina & 200.000 & 140.000 \\
\hline Nekretnine & 200.000 & 200.000 \\
\hline Oprema & 100.000 & 100.000 \\
\hline Amortizacija & $(100.000)$ & $(160.000)$ \\
\hline Kratkotrajna imovina & 210.000 & 862.454 \\
\hline Zalihe materijala & 9.000 & 19.000 \\
\hline Zalihe proizvoda & 30.000 & 48.609 \\
\hline Potraživanja & 90.000 & 180.000 \\
\hline Novac & 81.000 & 614.845 \\
\hline UKUPNO AKTIVA & 410.000 & 1.002 .454 \\
\hline Kapital i rezerve & 370.000 & 916.004 \\
\hline Upisani temeljni kapital & 300.000 & 300.000 \\
\hline Zadržana dobit & 70.000 & 70.000 \\
\hline Dobit razdoblja & 0 & 546.004 \\
\hline Dugoročne obveze & 0 & 0 \\
\hline Kratkoročne obveze & 40.000 & 86.450 \\
\hline Dobavljači & 40.000 & 86.450 \\
\hline UKUPNO PASIVA & 410.000 & 1.002 .454 \\
\hline
\end{tabular}

Izvor: vlastiti rad autora

Prema vertikalnoj analizi, na strani aktive bilance smanjuje se udio dugotrajne i povećava udio kratkotrajne imovine, dok se na strani pasive povećava udio kapitala i trajnih izvora financiranja, a smanjuje udio obveza. Kao rezultat takvih promijena u strukturi bilance, horizontalne analize bilance upućuje na rast likvidnosti i stabilnosti poslovanja, poduzetnika te rast slobodnih obrtnih sredstava (radni kapital) poduzetnika. 


\section{ZAKLJUČAK}

Proces upravljanja poslovanjem nezamisliv je bez barem minimalnog planiranja poslovanja. Planiranje poslovanja pak nezamislivo je bez odgovarajućih informacija, korisnici kojih su menadžeri koji donose poslovne odluke i upravljaju poslovnim procesima u poduzeću. Također, planiranje je nezamislivo i bez odgovarajuće kontrole i obrnuto, nezamisliva je kontrola bez planiranja. Za planiranje i kontrolu nužne su odgovarajuće informacije. Pored informacija s tržišta, za planiranje i kontrolu najvažnije su računovodstvene informacije koje pruža računovodstvena služba poduzeća, u okviru koje se upravljačkim računovodstvom uglavnom formaliziraju i kvantificiraju poslovi planiranja i kontrole.

S obzirom na vremenski rok planiranje se dijeli na dugoročno i kratkoročno. Dugoročnim se utvrđuju strateški ciljevi poduzetnika, kao i okvirna sredstva i upute za realizaciju tih ciljeva za vrijeme duže od tri godine. Kratkoročno planiranje podrazumijeva izradu glavnog poslovnog plana, odnosno master budžeta, kojim se za razdoblje od jedne godine ili kraće razdoblje preciznije utvrđuju ciljevi, sredstva i aktivnosti kojima se namjeravaju realizirati. Master budžet predstavlja skup pojedinačnih budžeta po dijelovima procesa u poduzeću, a koji zajedno čine skup planiranih aktivnosti za realizaciju planiranih ciljeva. Sastavni dio master budžeta je operativni plan, odnosno budžet kojim se planiraju (budžetiraju) poslovi za buduće obračunsko razdoblje poslovanja poduzeća i financijski plan kojim se planiraju novčani tokovi i konačni rezultati financijskog stanja poduzeća.

U ovom radu pošlo se od pretpostavke da se na jednostavnom primjeru poslove planiranja (budžetiranja) poslovanja prikaže prvenstveno za potrebe mikro i malih poduzetnika, kod kojih je funkcija planiranja zanemarena ili nedovoljno razvijena. Cilj rada je bio da se ukaže na značaj planiranja i izrade master budžeta, kako bi se pridonijelo sigurnijem donošenju upravljačkih odluka, koje će osigurati sigurnije poslovanje i razvoj poduzeća. Cilj rada je također pokazati kako se planiranjem utvrđuju, ne samo poslovni ciljevi i pretpostavke njihova ostvarivanja, nego i standardi koji će biti kriteriji kontrole realizacije poslovnih procesa kao i ispravljanja ili potvrđivanja planskih politika usklađenih s ciljevima.

U svakom dijelu rada se primjerenim uputama prikazao pristup i koraci u sastavljanju operativnog plana koji završava s planiranim (budžetiranim) računom dobiti i gubitka, kojim su sintetizirani svi elementi pojedinačnih buđeta po organizacijskim i poslovnim dijelovima poduzeća. Nastavno se prikazalo i sastavljanje financijskog plana s budžetiranim novčanim proračunom (novčani tok) i završnom planskom bilancom u kojoj su sinergijski prikazani konačni rezultati planiranja (budžetiranja) poslovanja. Jednostavnost prikaza izrade poslovnog plana omogućit će mikro i malim poduzetnicima da, koristeći prezentirani predložak, sami izrade svoj master budžet i definiraju ciljeve svog poslovanja za jednogodišnje razdoblje te predvide mjere kojima će ostvariti planirane ciljeve, ali i mjere za kontrolu ostvarivanja planiranih ciljeva. Na primjeren način prezentirani predložak mogu koristiti i veća poduzeća, naravno uz adekvatno analitičko proširenje podloga za planiranje ciljeva i mjera njihova ostvarivanja, prvenstveno u svrhu donošenja ispravnih upravljačkih odluka kojima će planirane ciljeve ostvarivati. 


\title{
BY BUDGETING TO SAFER BUSINESS OPERATIONS AND ENTERPRISE DEVELOPMENT
}

\author{
Željko Tintor, MSC \\ RETRA d.o.o. (Ltd) for auditing and business consulting \\ Lastovska 6., 10000 Zagreb, Croatia \\ GSM 091615 9292, e-mail: retra@zg.htnet.hr, web: www.retra.hr
}

\section{ABSTRACT}

The most important task of management is to make business decisions. Regardless of the type of decision, their ultimate goal is to ensure optimal business and profit, as well as future growth and development of the company. The risk of such decisions does not allow them to be made only on intuition, but requires reliable and credible information and thoughtful activities that will ensure the achievement of these goals. Among them, the most important management activity is budgeting, which is the foundation of business planning and managerial control over business processes and business results. With respect to the time frame, planning is divided into long-term and short-term. The former usually sets strategic goals over a period of three years or more, together with framework funds, broad guidelines and activities to achieve them, while the latter, called the master budget or the main business plan, covers a period of one year or a shorter period with more precise business objectives and more detailed means and activities by which they are intended to be realized. The master budget is a set of individual budgets or processes in the company that together form a synergy of planned activities of the future business of the company. Given the size of the company and the nature of its business, we distinguish between the master budget of a manufacturing and trading company. However, in both cases, planning as a process appropriately includes preparations for planning, defining goals, drafting and adopting a plan, as well as monitoring and analyzing the implementation of the plan. This paper is dedicated to the central part of planning, i.e. the development of the master budget, which, as the main business plan, includes the operating budget and financial budget of all business activities of the manufacturing company in a period of one year. As such, it represents a response to market challenges, uncertainties and business risks. With its simplicity of presentation, it is specially adapted for the needs of small companies, which make up the majority of economic entities in the Republic of Croatia. The aim of this paper is to point out the importance of the master budget and to present a complete model of the business plan of the manufacturing company and managerial control over all business processes. Also, the the paper intends to present a pattern according to which each company, from the smallest to the largest, can make its own annual master budget and thus ensure security and control of all business processes, and thus successful business, profit, growth and development. The paper uses techniques and methods of analysis and synthesis, as well as planning methods. The sources used in the paper are personal data sources and secondary sources, which include relevant professional and scientific literature.

Keywords: master budget; main business plan; operating budget; financial budget 


\section{LITERATURA}

1. Belak, V. (1995). Menadžersko računovodstvo. Zagreb: RRiF plus

2. Grupa autora (2015). Upravljačko računovodstvo: studija slučaja. Zagreb: HZRFD

3. Gulin, D., Janković, S., Dražić Lutilsky, I. et al. (2011). Upravljačko računovodstvo. Zagreb: HZRFD

4. Gulin, D., Tušek, B. i Žager, L. (2004). Poslovno planiranje, kontrola i analiza. Zagreb: HZRFD

5. Helfert, E. A. (1997). Tehnika financijske analize. Zagreb: HZRFD

6. Mamić Sačer, I., Sever, S., Žager, K. i Žager, L. (2008). Analiza financijskih izvještaja (2. prošireno izd.). Zagreb: Masmedia.

7. Meigs\&Meigs (1999). Računovodstvo temelj poslovnog odlučivanja. Zageb: Mate

8. Robert, N. A., James, S. R (2004). Računovodstvo, financijsko i upravljačko. Zagreb: RRIFplus

9. Tintor, Ž. (2014). Analiza financijskih izvještaja. Zagreb: Školska knjiga

10. Vasiljević, K. (1970). Teorija i analiza bilanca. Beograd: Savremena administracija 